\title{
RESENHA
}

\section{$O$ dom do crime: a literatura como território das (co)incidências}

Alexandre de Melo Andrade ${ }^{1}$

LUCCHESI, Marco. O dom do crime. Rio de Janeiro: Record, 2010.

Marco Lucchesi, embora ainda pouco estudado pela crítica literária, é uma das vozes mais singulares que surgiram nas últimas décadas no Brasil. Dedicando-se à poesia, à prosa de ficção e à crítica literária, o escritor aproxima os gêneros literários - o que é uma tendência desde a revolução romântica -, eliminando as fronteiras entre a linguagem da poesia e a linguagem da prosa, de modo a construir, ainda, uma crítica literária imbuída dos expedientes poéticos, o que provoca uma suspensão de nível maior: a obra literária (ficção) e a experiência (realidade). Dessa aproximação nasce $O$ dom do crime, publicado em 2010, onde o escritor - considerado até então apenas poeta e ensaísta - avança em direção a uma narrativa que reutiliza critérios instituídos em sua obra poética, de modo a deixar o leitor embaralhado entre a poesia e a prosa, a pesquisa estética e o acaso, a arte e o empirismo.

A narrativa possui como parâmetro a obra Dom Casmurro, de Machado de Assis. Há um narrador em primeira pessoa que se propõe, a pedido de seu médico, o Dr. Schimdt de Vasconcelos, a escrever um livro. Não se sabe muito desse narrador, a não ser que, entediado, vive apenas com uma gata de estimação chamada Graziela e com um mundo de livros de história, poesia e filosofia (o que aproxima o narrador do próprio autor: Marco Lucchesi é graduado em História, Doutor em Literatura e Pós-doutor em Filosofia), com os quais funda um universo próprio: "Não me casei. Vivo com Graziela, gata mal-humorada que me adotou. Não tive filhos e os poucos amigos desapareceram. Houve mesmo algum? Tenho muitos livros e poucas dívidas [...]” (p. 11). Ocupando-se

\footnotetext{
${ }^{1}$ Doutor em Estudos Literários - UNIESP/Ribeirão Preto. alexandremelo06@uol.com.br
} 
mais de falar sobre a vida alheia do que da sua própria vida, o narrador tem como núcleo a tragédia da personagem Helena Augusta, morta pelo marido no dia 06 de novembro de 1866, cujo motivo teria sido o adultério cometido com seu vizinho. Há aspectos que aproximam Helena de Capitu, como, por exemplo, a possibilidade de ambas terem enxergado no casamento uma possibilidade de ascensão social, além do adultério - duvidoso em Dom Casmurro, mas confesso em $O$ dom do crime. Neste sentido, a narrativa transcorre palmilhando a culpa de Helena e o assassinato cometido pelo marido, José Mariano. Todo crime cometido por ciúmes teria, assim, uma relação com o personagem machadiano; neste sentido, o ciúmes é o próprio "dom” do crime.

Há uma série de analogias que, a propósito, unem os dois escritores. Lucchesi, ao longo do romance, faz várias citações, na íntegra, do romance Dom Casmurro, de forma a entrecruzar as duas obras, explicitando razões e circunstâncias que aproximam as duas histórias. $\mathrm{O}$ excesso de detalhes e as digressões são, também, recursos explorados por Lucchesi; o narrador se dirige ao leitor e comenta o andamento da própria narrativa, corroborando para uma metalinguagem ao gosto machadiano. Um mapa do Rio de Janeiro antecede o primeiro capítulo, onde são apontadas, além de outras, as casas dos personagens que são acometidos por tragédias amorosas, de ambos os romances: casa de Capitu (Rua de Matacavalos), casa de Bentinho (Rua de Matacavalos), Casa de Machado de Assis (Rua de Matacavalos) e casa de Helena e Mariano. Nesta abertura do romance, já há o cruzamento entre as obras de ambos os autores, além da inserção do mundo real, aparente pela indicação da casa do próprio Machado de Assis, que aqui é escritor e personagem ao mesmo tempo. Lucchesi consegue, com isso, a aproximação entre a ficção e a realidade, como já aludimos, compreendendo a arte como a instância do possível, e o possível como instância da arte. Essa aproximação é comum no universo literário do autor de $O$ dom do crime, conforme ele mesmo atesta em entrevistas e textos de crítica.

Antes do posfácio, aparece outro mapa, com teor astrológico, indicando o "Céu do Rio, por volta da meia-noite do dia 06 de janeiro de 1866", data da morte de Helena Augusta. Mais uma vez aparece a coincidência entre os dois universos - intrínseco e extrínseco à obra -, amparada por uma ilusão que incorpora a relação entre autores, obras, personagens, histórias e procedimentos narrativos. O próprio nome do personagem que assassina a esposa - José Mariano - é similar ao do criador de Dom Casmurro - Joaquim Maria. Lucchesi parece conseguir, com todas essas coincidências, instituir a arte como o território da analogia, das aproximações, do diálogo permanente 
com o mundo real e com tantas outras obras. Este intento fica nítido, também, pela referência feita ao próprio Machado de Assis, no ano de 1900, quando o narrador de $O$ dom do crime começa a contar a história: "Machado de Assis vive encerrado nas páginas do Diário do Rio de Janeiro, em meio ao burburinho da rua do Ouvidor. [...] Tenciona deixar o Diário para assumir o posto de primeiro oficial na Secretaria da Agricultura, prometido por Afonso Celso [...]" (p. 31). Outra passagem que dá sentido ao que falamos é a seguinte: "Três anos depois da morte de Helena - que é quando se passa o conto 'A Cartomante' - Machado não perde ocasião de criar um triângulo amoroso entre Vilela, Rita e Camilo. [...]" (p. 63). O posfácio, que não pode deixar de ser lido, possui função dupla: de um lado esclarece a feitura da obra, de outro cria novos enigmas acerca da produção literária: “Como definir essas páginas inacabadas, de estilo flutuante, com os resquícios da velha oratória, imitando, de modo desastrado, algumas frases da narrativa machadiana [...]? Como definir um documento, em forma de diário, em que história e ficção tecem um diálogo ambíguo e rumoroso?” (p. 151).

O diálogo com a própria literatura e a história também acontece pela menção a tantos outros escritores, políticos e pessoas de prestígio do tempo romântico e realista. Lucchesi, no posfácio, fala do trabalho que teve em mapear, e até mesmo visitar, as ruas que apareceriam em seu romance, bem como da difícil e ao mesmo tempo instigante pesquisa acerca dos personagens que participaram da cena literária e política brasileira da segunda metade do século XIX. É claro que o romance exibe, dessa forma, a erudição de seu autor, e pode tornar o leitor desavisado alheio a uma série de coincidências implicadas na obra. Ainda que tal dificuldade de leitura exista, é de se dignificar o trabalho de Lucchesi, intelectual e apaixonado pelas letras, que, mesmo em seus poemas, funde essa erudição a contornos poéticos de extrema originalidade. Temse discutido muito a pluralidade trazida pela contemporaneidade, o que significa multiplicidade de vozes e diálogo permanente com a tradição; o romance de Lucchesi, não ficando à margem deste conceito, provoca diálogo com a tradição clássica e com a tradição moderna, o que reafirma o valor da tradição e reforça os vínculos com o melhor produzido pela modernidade. 